\author{
Andreas Rücker \\ Research Assistant \\ Technical University of Munich \\ Faculty of Mechanical Engineering \\ Chair of Materials Handling \\ Material Flow, Logistics (fml) \\ Germany \\ Jona Rief \\ Research Assistan \\ Technical University of Munich \\ Faculty of Mechanical Engineering \\ Chair of Materials Handling \\ Material Flow, Logistics (fml) \\ Germany \\ Johannes Fottner \\ Professor \\ Technical University of Munich \\ Faculty of Mechanical Engineering \\ Chair of Materials Handling \\ Material Flow, Logistics (fml) \\ Germany
}

\section{Development of a Method for the Energy Efficiency Determination of Stacker Cranes in Automated High-Bay Warehouses}

Modern intralogistic facilities fulfil important tasks within today's supply chains. Many different influences must be taken into account in their planning and construction. Current trends and circumstances show a strong tendency to build energy efficient and therefore environmentally friendly warehouses. This applies to the building technology of a warehouse and the intralogistic system used. Intralogistic facilities with an automated high-bay warehouse are very common and often operated by stacker cranes. This storage technology allows goods to be stored in a very volume and energy-efficient manner. The performance and energy demand of stacker cranes are influenced by a large number of parameters. To determine their energy efficiency is therefore complex. In this paper we present a method based on a simulation study which could be a possible solution for this problem.

Keywords: Intralogistics, High-bay warehouse, Automated storage and retrieval system, Stacker crane, Energy efficiency.

\section{INTRODUCTION}

In times of global climate change, ecological aspects are very important in every part of supply chains. This results in an increasing need to reduce the energy consumption in the physical part of the supply chain. Besides transport systems, intralogistic facilities are an important part of the physical supply chain. These circumstances also affect high-bay warehouses, which are an important part of intralogistic facilites. The energy consumption of automated high-bay warehouses is therefore of bigger concern to manufacturers and operators. These high-bay warehouses are often operated by stacker cranes (SCs). SCs are used to store, relocate and retrieve small load carriers, pallets or special load carriers inside the storage racks. Their energy demand and performance is influenced by a large number of variable effects which can only be optimised systematically.

Günthner et al. proposed in 2009 that a system for managing sustainability measures via an evaluation system would increase the opportunities for improvement [12]. They proposed to implement a control and measurement system before any improvements are made to measure their impact. Their system is based on four steps: 1. definition of sustainability key figures, 2 . establishing measurement systems, 3 . assessment of the status quo, and 4. identification, implementation and evaluation of improvements. Based on these results, we suggest an implementation cycle for energy effiency measures pictured in Figure 1. The cycle consists of

Received: May 2020, Accepted: July 2020

Correspondence to: Andreas Rücker, M.Sc.

Chair of Materials Handling, Material Flow, Logistics

Boltzmannstraße 15, 85748 Garching, Germany

E-mail: andreas.ruecker@tum.de

doi:10.5937/fme2004753R

(C) Faculty of Mechanical Engineering, Belgrade. All rights reserved four steps which are: assessment of the status quo, identifying potentials for improvements, implementing improvements and evaluating improvements. For the assessment and the evaluation, a method for the determination of the energy efficiency is needed.

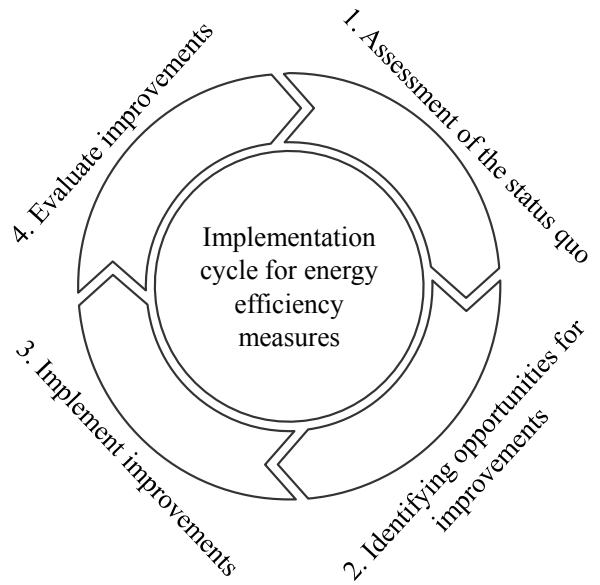

Figure 1. Implementation cycle for energy efficiency measures (compare [23])

The energy efficiency in public places is often linked to the EU energy efficiency label [8]. These labels are used for the classification of white goods like dishwashers, washing machines and refrigerators. They are helpful for consumers to gain a fast overview of the energy demand and to have the possibility to compare different machines. Labels like these are not common in the industrial environment. The rating for air filters [9] and the international efficiency code (IE-Code) for electric motors [4] are examples for the classification of individual machine components. The rating for elevators $[27$, 28] is an example for the classification of a whole machine. The energy efficiency classification is often based on a reference machine and a reference cycle. It is 
not feasible to define a reference SC because these machines are individually designed for a specific application. Thus we only use a reference cycle in our method.

In the field of intralogistics, there is currently only one new guideline for the energy consumption determination available [29]. This guideline also contains a method to calculate the energy consumption of an SC. In a former paper [24], we presented an investigation of the mean energy demand and the performance of SCs. The simulation model which was used for the investigation in this paper is based on the FEM guideline. This paper uses the results of the conducted simulation study to develop a meta model for the determination of the mean energy demand and furthermore for the energy efficiency determination of SCs. Subsequently, we presented a possible method to develop classes for the energy efficiency labelling. We repeated our suggestion to use the FEM reference cycle for the mean energy demand determination. This work aims to be a contribution to improve the energy efficiency of SCs.

\section{LITERATURE}

The change to green intralogistics was examined by Altintas et al. [1] in 2010. The research work especially shows potential for intralogistics by sampling and analysing literature of different optimisation potentials in intralogistics. They also conducted an expert survey to test the industry's views on green logistics. Their research work is based on the roadmap for sustainable intralogistics from Günthner et al. [12]. Optimising the energy efficiency in intralogistics was also part of the research work of Lottersberger and Hafner. They investigated the energy efficiency of material flow systems $[13,14]$ with a focus on continuous conveyors.

A modern approach for optimising the investment expenses, the cycle times and the $\mathrm{CO}_{2}$ footprint for automated storage and retrieval systems was presented by Rajkovic et al. [21]. They presented a multi-objective optimisation model to simultaneously consider the different design criteria of automated storage and retrieval systems.

The impact of the design options in intralogistics and building design on the overall energy demand and $\mathrm{CO}_{2}$ emissions was part of the research work of Freis et al. [11]. They investigated three reference intralogistics facilities with different degrees of automation. One of their conclusions was the significant increase of the energy demand with increasing automation.

The last review paper presenting a literature survey on SCs was presented by Roodbergen [22], followed by a review paper in 2016 by Boysen and Stephan with a focus on scheduling tasks of SCs [2]. The energy demand of SCs was part of various publications in recent years. Meneghetti et al. focused their research work on the influence of strategic parameters [17-20]. Lerher et al. presented a first method for calculating the energy efficiency of miniload stacker cranes (MSCs) [16]. Ertl et al. also investigated energy demand and the energy efficiency of SCs and presented a method for energy efficiency classes for MSCs [5, 6]. A method for the benchmarking of different types of automated storage and retrieval systems was presented by Stöhr et al. [25].
They proposed the use of the standard double cycle from VDI 3561 [26] as a reference cycle for the comparison between MSCs, shuttle systems and horizontal carousel systems.

The energy demand of pallet stacker cranes (PSCs) has only been investigated by Braun and Furmans [3]. Their work was focused on the the calibration of a simulation model to anticipate the energy demand of a specific SC. In their work, they did not investigate superordinate relationships for a large number of PSCs. With our work, we try to close this research gap.

\section{MATERIALS AND METHODS}

A typical scheme of an SC and the nomenclature used in the paper is shown in Figure 2. Because of their fundamentally different mass ratios, we distinguish between MSCs and PSCs in the analyses in this work.

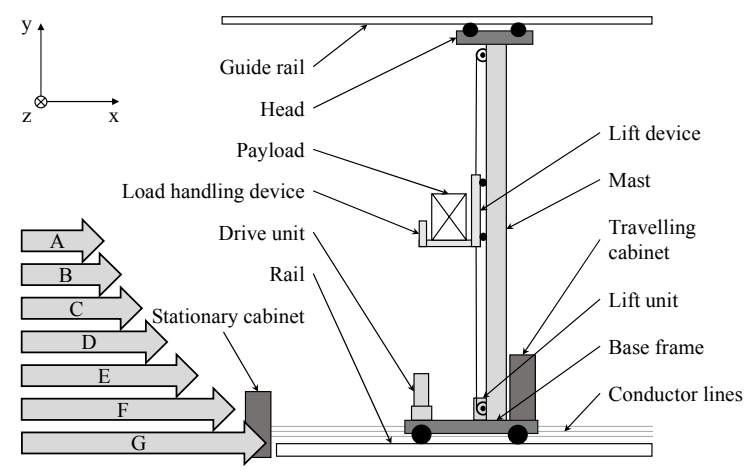

Figure 2. Scheme of a stacker crane (compare [23])

In addition, we symbolically represent the energy efficiency classes from $A$ to $G$, which will later be proposed for classification. The main components are the base frame, the mast, the head, the lifting device with load handling device and the drives. SCs have two main drives for the horizontal and vertical movement of the payload. The power supplies of the main drives are electrically connected via a DC link [24]

In the paper we present an approach for the energy efficiency determination of an SC. Before we specify the method, we present a simple meta model of the energy demand of an SC using the FEM cycle. Both methods are based on the results of the simulation study performed in [24]. The list of varied parameters which specify the SC configurations in the simulation study is shown in Table 1.

Table 1. List of the varied parameters and their maximum and minimum values for MSC and PSC [24]

\begin{tabular}{|c|c|c|c|c|}
\hline Parameter & $\begin{array}{c}\text { MSC } \\
\text { min }\end{array}$ & $\begin{array}{c}\text { MSC } \\
\text { max }\end{array}$ & $\begin{array}{c}\text { PSC } \\
\text { min }\end{array}$ & $\begin{array}{c}\text { PSC } \\
\text { max }\end{array}$ \\
\hline Number of columns $n_{\text {col }}$ & 30 & 80 & 20 & 60 \\
\hline Number of levels $n_{\text {lev }}$ & 20 & 40 & 8 & 18 \\
\hline $\begin{array}{c}\text { Acceleration drive unit } \\
a_{x}\end{array}$ & $2 \mathrm{~m} / \mathrm{s}^{2}$ & $5 \mathrm{~m} / \mathrm{s}^{2}$ & $0.5 \mathrm{~m} / \mathrm{s}^{2}$ & $\begin{array}{c}1.5 \\
\mathrm{~m} / \mathrm{s}^{2}\end{array}$ \\
\hline Acceleration lift unit $a_{v}$ & $1 \mathrm{~m} / \mathrm{s}^{2}$ & $3 \mathrm{~m} / \mathrm{s}^{2}$ & $0.2 \mathrm{~m} / \mathrm{s}^{2}$ & $1 \mathrm{~m} / \mathrm{s}^{2}$ \\
\hline Velocity drive unit $v_{x}$ & $4 \mathrm{~m} / \mathrm{s}$ & $6 \mathrm{~m} / \mathrm{s}$ & $1.5 \mathrm{~m} / \mathrm{s}$ & $3.5 \mathrm{~m} / \mathrm{s}$ \\
\hline $\begin{array}{c}\text { Velocity lift unit } \\
v_{y} \text { in m/s } / \mathrm{s}\end{array}$ & $1.5 \mathrm{~m} / \mathrm{s}$ & $3 \mathrm{~m} / \mathrm{s}$ & $0.5 \mathrm{~m} / \mathrm{s}$ & $2 \mathrm{~m} / \mathrm{s}$ \\
\hline $\begin{array}{c}\text { Efficiency drive and lift } \\
\text { unit } \eta_{x}, \eta_{v}\end{array}$ & 0.4 & 0.7 & 0.4 & 0.7 \\
\hline Mass base frame $m_{\text {base }}$ & $1.2 \mathrm{t}$ & $2 \mathrm{t}$ & $8 \mathrm{t}$ & $20 \mathrm{t}$ \\
\hline
\end{tabular}




\begin{tabular}{|c|c|c|c|c|}
\hline Parameter & $\begin{array}{c}\text { MSC } \\
\text { min }\end{array}$ & $\begin{array}{c}\text { MSC } \\
\text { max }\end{array}$ & $\begin{array}{c}\text { PSC } \\
\text { min }\end{array}$ & $\begin{array}{c}\text { PSC } \\
\text { max }\end{array}$ \\
\hline Mass lift unit $m_{L u}$ & $250 \mathrm{~kg}$ & $450 \mathrm{~kg}$ & $2.5 \mathrm{t}$ & $4.5 \mathrm{t}$ \\
\hline Mass payload $m_{\text {load }}$ & $25 \mathrm{~kg}$ & $75 \mathrm{~kg}$ & $0.5 \mathrm{t}$ & $1.5 \mathrm{t}$ \\
\hline Storage occupancy $O_{C C}$ & 0.4 & 0.9 & 0.4 & 0.9 \\
\hline Use of a refeed unit $R U$ & 0 & 1 & 0 & 1 \\
\hline
\end{tabular}

In between these minimum and maximum values of each parameter, we used 20,000 different SC configurations selected by a Latin hypercube sampling algorithm for the simulation study. We used 5,000 different SC configurations for MSC and PSC, either with (RU1) or without (RU0) a refeed unit. The refeed unit can feed electrical energy back into the grid, thus reducing the energy demand. We evaluated the mean energy demand and the throughput for each configuration during a large number of randomly created operation cycles. Subsequently, the data was used to find a suitable reference cycle. We developed two different ways for calculating a reference cycle and compared it with the FEM 9.851 [10] reference cycle. In our comparison, the FEM cycle was the best possible cycle for our purposes. It allowed the determination of the mean energy demand of an SC using just one double cycle and minimum error.

\subsection{Meta modelling the energy demand of a stacker crane}

Figures 3 and 4 show the results of the simulation study with the correlations of the energy demand and the throughput (TP) and the varied parameters. Figure 3 shows the correlations for the MSC double cycle configurations without a refeed unit (RU0).

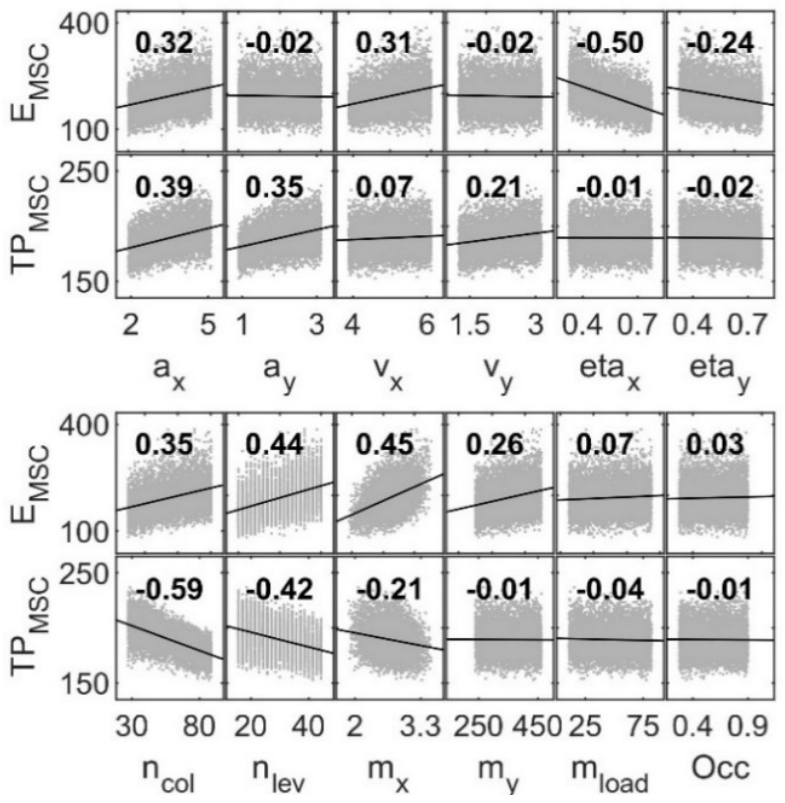

Figure 3. Correlations for the MSC double cycle configurations without a refeed unit and with TP in moved items per hour and $E$ in $\mathrm{kJ}$ [24]

Furthermore, Figure 4 shows the correlations for the PSC double cycle configurations with a refeed unit (RU1).

Based on these results, we showed in [24] that the mean energy demand could be assumed by using the reference double cycle from FEM 9.851 [10]. It is also very well approved as a reference cycle for the mean cycle time. The FEM double cycle is pictured in Figure 5.

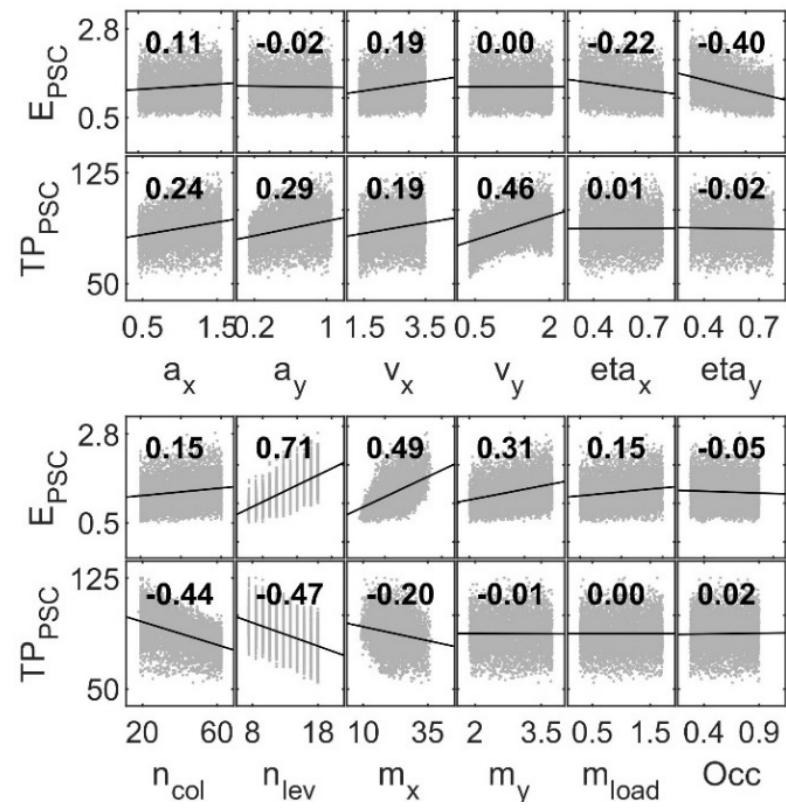

Figure 4. Correlations for the PSC double cycle configurations without a refeed unit and with TP in moved items per hour and E in MJ [24]

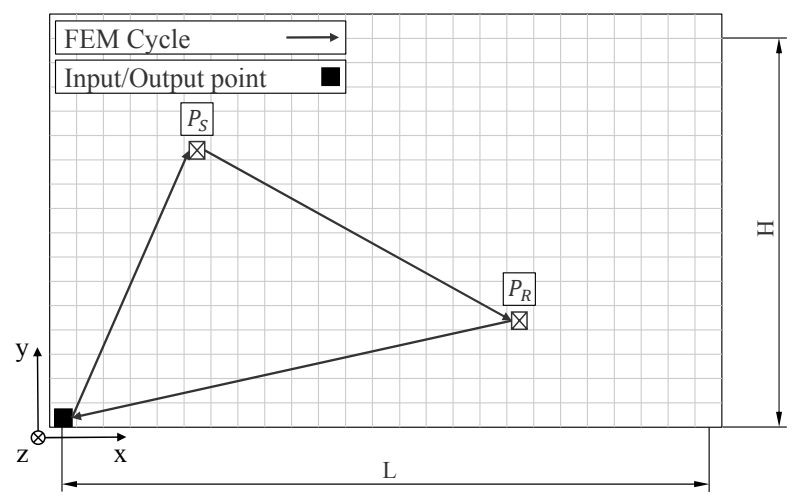

Figure 5. Double cycle from FEM 9.851 [10]

For the FEM cycle the store and retrieve position are defined in (1) with $\mathcal{L}$ as the rack length and $H$ as the rack height.

$$
\begin{aligned}
& \text { Store position: } P_{\mathrm{R}}\left(\frac{1}{5} \cdot L, \frac{2}{3} \cdot H\right) \\
& \text { Retrieve position: } P_{\mathrm{R}}\left(\frac{2}{3} \cdot L, \frac{1}{5} \cdot H\right)
\end{aligned}
$$

Firstly a store cycle from the I/O point to the store position, secondly a drive from the store to the retrieve point and thirdly a retrieve cycle from the retrieve position back to the I/O point are performed. We focused our investigations on the reference double cycle.

The simulation results of the 20,000 configurations for the correlation between the overall mean energy demand and the energy demand for one FEM double cycle are shown in Figures 6 and 7. The results are split into MSC and PSC and are displayed with the 
corresponding error distribution. We discovered a strong indication for a linear correlation in both cases.
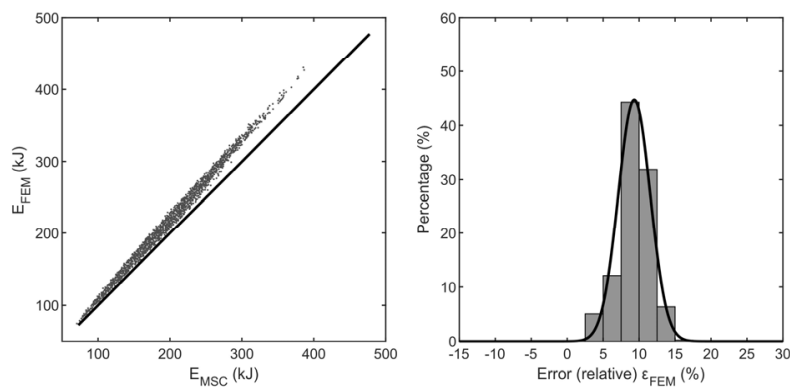

Figure 6. Correlation for the overall mean energy demand and the energy demand of an FEM double cycle with the corresponding relative error for MSC

The error distribution is somewhat narrower for MSC and has a lower mean error than for PSC.
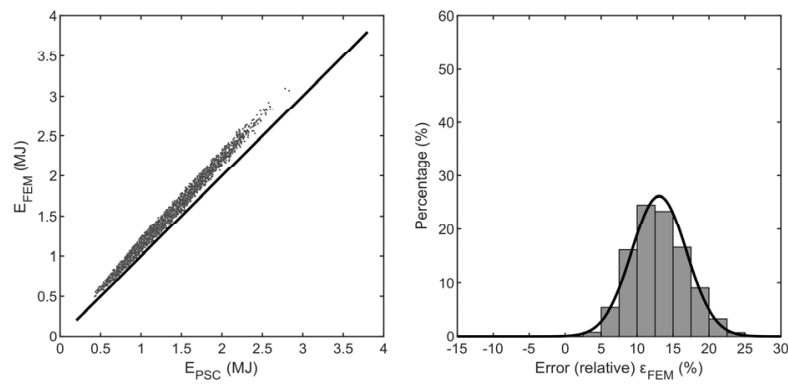

Figure 7. Correlation for the overall mean energy demand and the energy demand of an FEM double cycle with the corresponding relative error for PSC

Based on the simulation results, the FEM double cycle leads to an overestimation of the mean energy demand of approximately $10 \%$. Because of this relation, we propose a simple linear model to calculate the overall mean energy demand $\hat{E}_{\mathrm{M}}$ with the energy demand of an FEM double cycle $E_{\mathrm{FEM}}$ in equation (2).

$$
\hat{E}_{\mathrm{M}}\left(E_{\mathrm{FEM}}\right)=c_{\mathrm{FEM}} \cdot E_{\mathrm{FEM}}
$$

For the double cycles of MSC and PSC in all configurations, we evaluated a correction factor $c_{\mathrm{FEM}}=0.891$. The results for the residual energy demand values and the relative error for different configurations are presented in section 4.1.

\subsection{Describing the energy efficiency of stacker cranes}

In general the energy efficiency is defined in the EU directive 2012/27/EU as the ratio of output of performance, service, goods or energy to input energy [7]. The main definition of energy efficiency can be stated with (3) with the performance $\Phi$ and the electrical energy demand $E_{e l}$ to achieve this performance. The nomenclature is based on the definition from Ertl [5]. He used the reciprocal value of $k_{\mathrm{EE}}$ for his work.

$$
k_{\mathrm{EE}}=\frac{\Phi}{E_{\mathrm{el}}}
$$

The performance definition of the $\mathrm{SC}$ is based on mass flow and volume capacity of the storage rack.
Equation (4) states the definition for the performance $\Phi$. It contains throughput $\lambda$, the mean transported payload mass $\bar{m}_{\text {load }}$, the number of columns $n_{\text {col }}$ and levels $n_{\text {lev }}$ and the volume of a storage compartment $V_{\text {Unit. }}$. The throughput represents the number of load units moved per time unit.

$$
\Phi=\lambda \cdot \bar{m}_{\mathrm{load}} \cdot n_{\mathrm{col}} \cdot n_{\mathrm{lev}} \cdot V_{\text {Unit }}
$$

Lerher used also the warehouse volume as a performance measure for a shuttle based storage and retrieval system [15]. The combination of the selected parameters should be suitable for the consideration of the performance. The energy demand $E_{\text {el }}$ can also be expressed through the mean electrical power $\bar{P}_{e l}$, the throughput $\lambda$ and the number of transported load units in the review period $n_{\text {load }}$.

$$
E_{\mathrm{el}}=\frac{\bar{P}_{\mathrm{el}} \cdot n_{\mathrm{load}}}{\lambda}
$$

Combining the equations (3), (4) and (5), we get the full definition for the energy efficiency key figure with either energy demand or mean electrical power (6).

$$
k_{\mathrm{EE}}=\frac{\lambda \cdot \bar{m}_{\mathrm{load}} \cdot n_{\mathrm{col}} \cdot n_{\mathrm{lev}} \cdot V_{\mathrm{Unit}}}{E_{\mathrm{el}}}
$$

The calculation method executed for all configurations leads to the resulting distribution of $k_{\mathrm{EE}}$ for MSC in Figure 8 and for PSC in Figure 9.

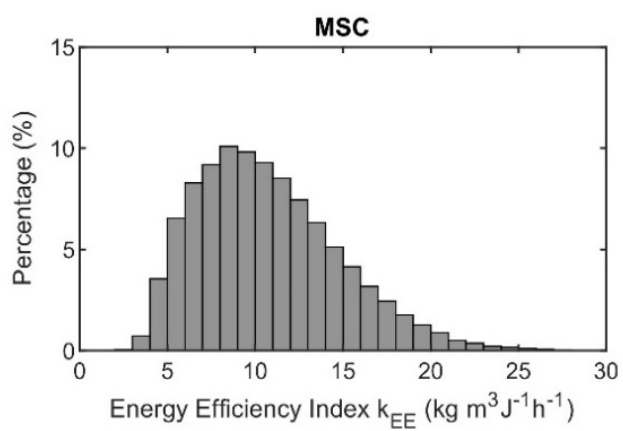

Figure 8. Distribution of the energy efficiency index $k_{E E}$ for MSC

The figures for PSC are higher than for MSC by a factor of ten. Both distributions indicate a moved standard distribution of the energy efficiency index. The whole range is based on the parameter space from Table 1. The distributions are used to apply different classification methods. The results are shown in Section 4.2.

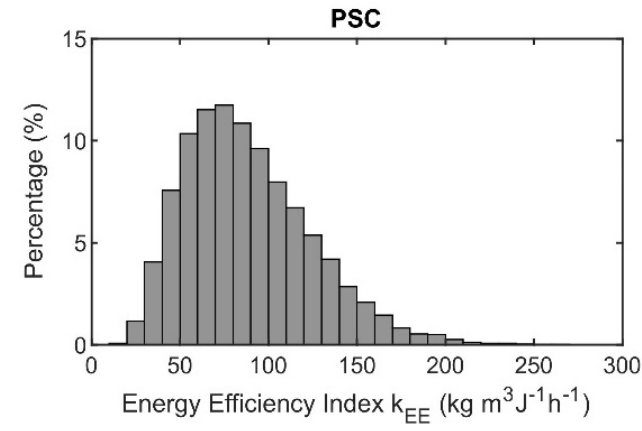

Figure 9. Distribution of the energy efficiency index $k_{\mathrm{EE}}$ for PSC

FME Transactions 


\section{RESULTS}

The results section is split into two different parts. First, we show the results from our metamodelling and error correction of the energy demand with the FEM cycle. Second, we state the results for three different distribution methods of energy efficiency classes.

\subsection{Metamodelling the mean energy demand with the FEM cycle}

Using the described correction factor from Section 3.1, we get the following results for different configurations. To have a more detailed insight, we split the results for MSC and PSC in the 5,000 configurations without (RU0) and with (RU1) a refeed unit. The resulting residuals (difference between overall mean energy demand and estimated energy demand) for the different configurations are shown in Figure 10. The residuals are mainly evenly distributed, except for individual outliers.
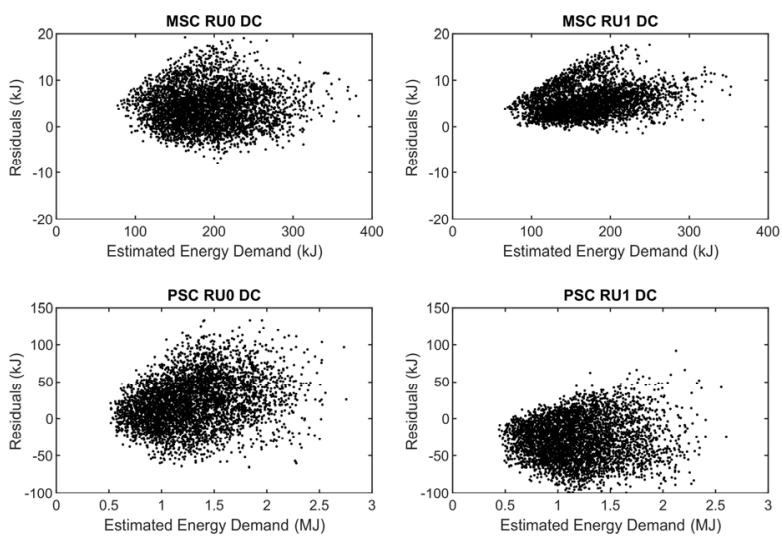

Figure 10. Residuals for the overall mean energy demand and the energy demand of an FEM double cycle

The resulting relative error distributions in Figure 11 indicate small relative errors with mostly an overestimation of the mean energy demand. Only the PSC configurations without a refeed unit are mostly underestimated.
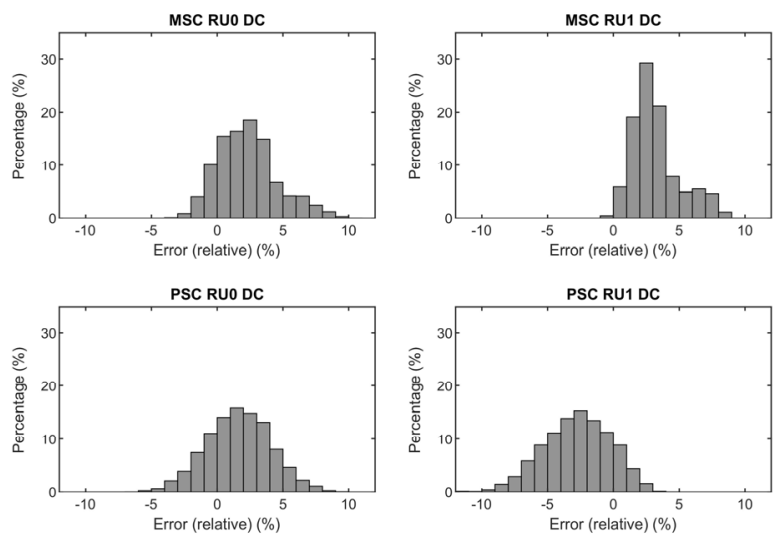

Figure 11. Relative error of an FEM double cycle related to the overall mean energy demand

Table 2 lists the values for the error distributions in Figure 11. To keep the absolute value of the mean error at a lower level, we accepted the overestimation in some of the configurations.
Table 2. Mean, minimum and maximum error values and the share of configurations with an absolute error smaller or equal to $10 \%$ for the double cycle configurations in $\%$

\begin{tabular}{|c|c|c|c|c|}
\hline Configuration & $\varepsilon_{\text {mean }}$ & $\varepsilon_{\min }$ & $\varepsilon_{\max }$ & $P(|\varepsilon \leq 10 \%|)$ \\
\hline MSC, RU0 & 2.3 & -3.8 & 11.8 & 99.94 \\
\hline MSC, RU1 & 3.2 & -0.7 & 9.1 & 100 \\
\hline PSC, RU0 & 1.6 & -6.1 & 10.2 & 99.98 \\
\hline PSC, RU1 & -2.8 & -12.0 & 4.8 & 99.7 \\
\hline
\end{tabular}

\subsection{Energy efficiency class determination}

In this section, we introduce three different possibilities to build seven efficiency classes from A to G. The stated definition of the energy efficiency index seems to lead to a moved normal distribution of $k_{\mathrm{EE}}$ over the simulated configurations (see Figures 8 and 9). To split these ranges into different efficiency classes, we used five symmetric intervals with an interval range of one standard deviation $\sigma$ in the range of $\pm 2.5 \sigma$, an additional interval over $+2.5 \sigma$ and below $-2.5 \sigma$. The corresponding percentile, the share and the limit values for the seven intervals are displayed in Table 3.

Table 3. Energy efficiency class limit values based on a standard distribution

\begin{tabular}{|c|c|c|c|c|}
\hline Class & $\begin{array}{c}\text { Per- } \\
\text { centile }\end{array}$ & Share & $\begin{array}{c}\text { MSC } \\
k_{\mathrm{EE}, \min } \\
\text { in } \frac{\mathrm{kg} \cdot \mathrm{m}^{3}}{\mathrm{~J} \cdot \mathrm{h}}\end{array}$ & $\begin{array}{c}\text { PSC } \\
k_{\mathrm{EE}, \mathrm{min}} \\
\text { in } \frac{\mathrm{kg} \cdot \mathrm{m}^{3}}{\mathrm{~J} \cdot \mathrm{h}}\end{array}$ \\
\hline $\mathrm{A}$ & $0.62 \%$ & $0.62 \%$ & 19.38 & 185.81 \\
\hline $\mathrm{B}$ & $6.7 \%$ & $6.1 \%$ & 15.04 & 138.41 \\
\hline $\mathrm{C}$ & $30.9 \%$ & $24.2 \%$ & 10.81 & 97.10 \\
\hline $\mathrm{D}$ & $69.1 \%$ & $38.3 \%$ & 7.24 & 63.37 \\
\hline $\mathrm{E}$ & $93.3 \%$ & $24.2 \%$ & 4.77 & 40.27 \\
\hline $\mathrm{F}$ & $99.4 \%$ & $6.1 \%$ & 3.51 & 25.74 \\
\hline $\mathrm{G}$ & $100 \%$ & $0.62 \%$ & 0 & 0 \\
\hline
\end{tabular}

Using these values, we can split our four different basic configurations into the seven classes. The resulting class distributions show that naturally the share of higher efficient SCs is higher with the use of a refeed unit (see Figure 12). Combining the results for RU0 and RU1 would lead to the normal distribution with the shares listed in Table 3.

In addition to the normal distribution-based split and for a better assessment, we tried out two other distribution methods. The first is based on a linear series and the second is based on a geometric series. The linear series starts with the limit value of class A from the standard distribution $k_{\mathrm{EE}, 1}$ and is built with the distance between two classes $d_{k \mathrm{EE} \text {,lin }}$ using equation (7).

$$
k_{\mathrm{EE}, \mathrm{i}, \text { lin }}=k_{\mathrm{EE}, 1}-d_{\mathrm{kEE}, \text { lin }} \cdot i
$$

Splitting the classes with a linear series leads to a less uniform distribution compared to the normal distribution. The results in Figure 13 show a not necessarily desired shift of the main class towards E.

The geometric series is based on a logarithmic distribution. Ertl also used a geometric series to develop his classification [5]. The distribution with the logarithmic factor $d_{k \mathrm{EE}, \log }^{i}$ is built using equation (8).

$$
k_{\mathrm{EE}, \mathrm{i}, \log }=k_{\mathrm{EE}, 1} \cdot d_{\mathrm{kEE}, \log }^{i}
$$



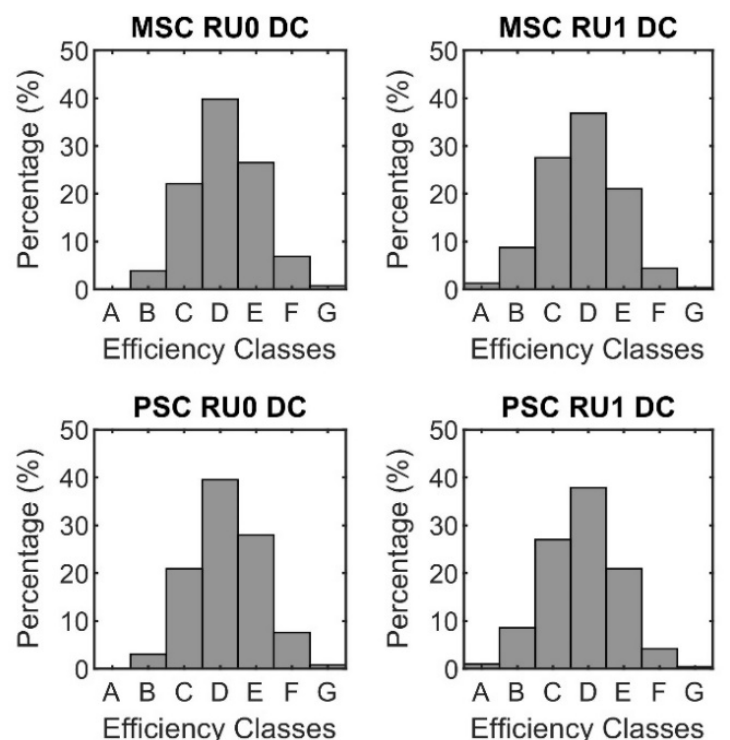

Figure 12. Classification of the energy efficiency based on a normal distribution
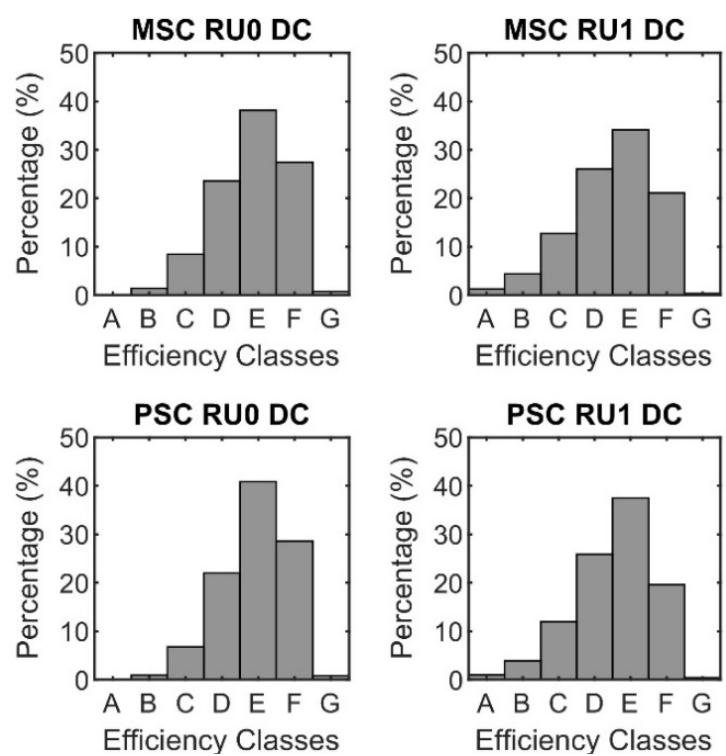

Figure 13. Classification of the energy efficiency based on a linear series
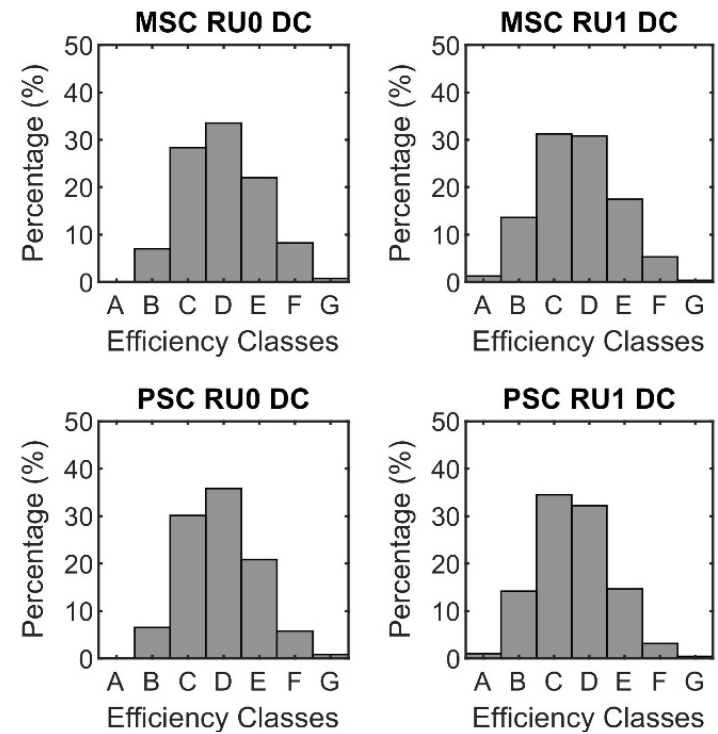

Figure 14. Classification of the energy efficiency based on a geometric series
Applying the logarithmic distribution results in a more uniform distribution compared to the linear distribution. The resulting class distributions (see Figure 14) are similar compared to the standard distribution ones.

In the comparison between the classification on the basis of normal distribution and on the basis of the geometric row, we cannot find a clear advantage for either method. The calculation parameters for the linear and geometric distribution are listed in Table 4.

Table 4. Parameters for calculating the limit values for linear and logarithmic distribution

\begin{tabular}{|c|c|c|c|}
\hline Type & $\begin{array}{c}k_{\mathrm{EE}, 1} \\
\text { in } \\
\frac{\mathrm{kg} \cdot \mathrm{m}^{3}}{\mathrm{~J} \cdot \mathrm{h}}\end{array}$ & $\begin{array}{c}d_{\mathrm{kEE}, \mathrm{lin}} \\
\text { in } \frac{\mathrm{kg} \cdot \mathrm{m}^{3}}{\mathrm{~J} \cdot \mathrm{h}}\end{array}$ & $k_{\mathrm{kEE}, \mathrm{log}}$ \\
\hline MSC & 19.38 & 3.173 & 0.711 \\
\hline PSC & 185.81 & 32.014 & 0.673 \\
\hline
\end{tabular}

\section{CONCLUSION}

Based on the results of a simulation study, we developed a simplified method to calculate the overall mean energy demand with the help of the FEM reference cycle. To achieve this, we introduced a correction factor $c_{\mathrm{FEM}}$ to reduce the error for the estimated mean energy demand.

We also proposed a method for calculating an energy efficiency index. The energy efficiency index takes the throughput and the storage volume into account and correlates it to the energy demand. We used this energy efficiency index and developed three different methods to build efficiency classes. Because of the even class distribution, the best way to build the efficiency classes is the classification based on a normal distribution. It is based on the normal distribution of the energy efficiency index and should therefore best match the physical conditions.

Our further research is focused on the investigation of strategic parameters in the operation of stacker cranes. These strategic parameters, for instance the storage bin allocation, are very important for the application of SCs. Finally, we will deal with the practical applicability of the method for energy efficiency classification.

\section{ACKNOWLEDGEMENTS}

The research has been conducted on the basis of the industrielle Gemeinschaftsforschung [collective industrial research] (iGF) project "Entwicklung einer Bewertungsmethodik für die Energieeffizienz eines Regalbediengerätes" (iGF project number 18839N). This project has been funded by the Federal Ministry for Economic Affairs and Energy on the basis of a decision of the German Bundestag [Federal Parliament].

\section{REFERENCES}

[1] Altintas, O., Avsar, C., Klumpp, M., Ag, D.: Change to Green in Intralogistics, Conference Proceedings, pp. 373-377, 2010.

[2] Boysen, N., Stephan, K.: A survey on single crane scheduling in automated storage/retrieval systems, 
European Journal of Operational Research, Vol. 254, No. 3, pp. 691-704, 2016.

[3] Braun, M., Furmans, K.: Evaluation of simulation models for forecasting the energy demand of storage and retrieval machines with empirically collected measurement data (German), Logistics Journal Proceedings, 2016.

[4] German Institute for Standardization: Adjustable speed electrical power drive systems - Part 9-1: Energy efficiency of power systems, motor starters, power electronics and their driven equipment (German), DIN EN 61800, 2018.

[5] Ertl, R.: Energy demand determination and energy efficiency assessment of storage and retrieval machines in automatic small parts warehouses, (German), PhD Thesis, Technical University of Munich, 2016.

[6] Ertl, R., Willibald A., G.: Meta-model for calculating the mean energy demand of automated storage and retrieval systems, Logistics Journal, 2016.

[7] European Parliament: Directive 2012/27 of the European Parliament and of the Council of 25 October 2012 on energy efficiency, 2012/27/EU, 2012.

[8] European Parliament: Regulation 2017/1369 setting a framework for energy labelling, 2017/1369/EU, 2017.

[9] Eurovent Certita Certification: Rating Standard tor the Certification of Air Filters, RS4/C/001-2015, 2015.

[10] European Materials Handling Federation: Performance record for storage and retrieval machines - Cycle times, FEM 9.851, 2003.

[11] Freis, J., Vohlidka, P., Günthner, W.: Low-Carbon Warehousing: Examining Impacts of Building and Intra-Logistics Design Options on Energy Demand and the $\mathrm{CO} 2$ Emissions of Logistics Centers, Sustainability, Vol. 8, No. 448, pp. 1-36 2016.

[12] Günthner, W.A., Galka, S., Tenerowicz-Wirth, P.: Roadmap for sustainable intralogistics (German), In: Ziems, D., Inderfurth, K., Schenk, M., Wäscher, G., Zadek, H. (eds.), Sustainable Logistics, 14. Scientific symposium Magdeburg, pp. 205-220, 2009.

[13] Hafner, N., Lottersberger, F.: Energy Efficiency in Material Flow Systems (effMFS). FME Transaction, Vol. 40, No. 4, pp. 181-186, 2012.

[14] Hafner, N., Lottersberger, F.: Intralogistics systems - optimization of energy efficiency. FME Transactions, Vol. 44, No. 3, pp. 256-262, 2016.

[15] Lerher, T.: Design of Experiments for Identifying the Throughput Performance of Shuttle-Based Storage and Retrieval Systems, Procedia Engineering, Vol. 187, pp. 324-334, 2017.

[16] Lerher, T., Edl, M., Rosi, B.: Energy efficiency model for the mini-load automated storage and retrieval systems, International Journal of Advanced Manufacturing Technology, Vol. 70, pp. 97-114, 2014.

[17] Meneghetti, A., Monti, L.: Energy Efficient Dual Command Cycles in Automated Storage and Retrieval Systems, Proceedings World Renewable Energy Congress Sweden, pp. 1668-1675, 2011.
[18] Meneghetti, A., Monti, L.: Multiple-weight unit load storage assignment strategies for energy efficient automated warehouses, International Journal of Logistics Research and Applications, Vol. 17, No. 4, pp. 304-322, 2013.

[19] Meneghetti, A., Monti, L.: Sustainable storage assignment and dwell-point policies for automated storage and retrieval systems, Production Planning \& Control: The Management of Operations, Vol. 24, No. 6, pp. 511-520, 2013.

[20] Meneghetti, A., Dal Borgo, E., Monti, L.: Rack shape and energy efficient operations in automated storage and retrieval systems, International journal of production research, Vol. 53, No. 23/24, pp. 7090-7103, 2015.

[21] Rajković, M., Zrnić, N., Kosanić, N., Borovinšek, M., Lerher, T.L.: A multi-objective optimization model for minimizing investment expenses, cycle times and $\mathrm{CO} 2$ footprint of an automated storage and retrieval systems, Transport, Vol. 34, No. 3, pp. 275-286, 2019.

[22] Roodbergen, K.J., Vis, I.F.A.: A survey of literature on automated storage and retrieval systems, European Journal of Operational Research, Vol. 194, No. 2, pp. 343-362, 2009.

[23] Rücker, A., Fottner, J.: Development of a multicomponent evaluation methodology for the energy efficiency of stacker cranes (German), Logistics Journal Proceedings, pp. 115 - 125, 2018.

[24] Rücker, A., Rief, J., Fottner, J.: An investigation of mean energy demand, performance and reference cycles for stacker cranes, FME Transactions, Vol. 48, No. 2, pp. 307-312, 2020.

[25] Stöhr, T., Schadler, M. Hafner, N.: Benchmarking the energy efficiency of diverse Automated Storage and Retrieval Systems, FME Transactions, Vol. 46, No. 3, pp. 330-335, 2018.

[26] Association of German Engineers: Test games for performance comparison and approval of storage and retrieval machines (German), VDI 3561,1973.

[27] Association of German Engineers: Lifts - Energy efficiency (German), VDI 4707-1, 2009.

[28] Association of German Engineers: Lifts - Energy efficiency of components (German), VDI 4707-2, 2013.

[29] European Materials Handling Federation: Energy consumption - determination methods (ECoDeMISE), FEM 9.865, 2017.

\section{РАЗВИЈАЊЕ МЕТОДЕ ЗА ОДРЕЪИВАЊЕ ЕНЕРГЕТСКЕ ЕФИКАСНОСТИ ДИЗАЛИЦЕ ЗА СЛАГАЊЕ РОБЕ У АУТОМАТИЗОВАНИМ ВИСОКОРЕГАЛНИМ СКЛАДИШТИМА}

\section{А. Рукер, Ј. Риф, Ј. Фотнер}

Савремени интралогистички објекти извршавају важне задатке у ланцу снабдевања робом. Приликом планирања и изградње ових објеката морају се узети у обзир бројни утицајни фактори. Данашњи тренд и околности показују да је потребно градити енергетски ефикасна и за околину безбедна складишта. То 
се односи на технологију изградње складишта и коришћење интралогистичког система. У употреби су интралогистички објекти са високорегалним складиштима у којима се најчешће користе дизалице за слагање на регале. Таква технологија складиштења омогућава велики складишни капацитет и обезбеђује енергетску ефикасност. Велики број параметара утиче на перформансе и енергетске потребе дизалица. Према томе, одређивање енергетске ефикасности дизалица представља комплексан проблем. У раду је приказан метод базиран на симулацији који би могао да буде могуће решење овог проблема. 